\title{
Isocyanates in marine sponges: Axisocyanate-3, a new sesquiterpene from Acanthella cavernosa
}

\author{
Pinus Jumaryatno, ${ }^{\mathrm{a}, \mathrm{b}}$ Karen Rands-Trevor, ${ }^{\mathrm{a}}$ Joanne T. Blanchfield, ${ }^{\mathrm{a}}$ and Mary J. Garson ${ }^{\mathrm{a} *}$ \\ ${ }^{a}$ School of Molecular and Microbial Sciences, The University of Queensland, Brisbane QLD \\ 4072, Australia \\ ${ }^{b}$ Department of Pharmacy, Islamic University of Indonesia, Yogyakarta 55584, Indonesia \\ E-mail:m.garson@uq.edu.au
}

Dedicated to Professor Atta-ur-Rahman FRS on the occasion of his $65^{\text {th }}$ birthday

\begin{abstract}
The isolation of axisocyanate-3 as a minor component of Acanthella cavernosa has been confirmed by spectroscopic characterisation of the metabolite, and by conversion of a mixture of axisothiocyanate- 3 and axisocyanate- 3 to their diethyl(thio)urea derivatives. The role of isocyanates in the formation of urea metabolites in sponges has been investigated through a model study with a menthyl-derived isocyanate.
\end{abstract}

Keywords: Sesquiterpenoid, isocyanate, urea, NMR, sponges

\section{Introduction}

Bioactive terpenes functionalized by the presence of isocyano, isothiocyanato and formamide groups are a common structural motif in marine sponge chemistry. Much less commonly encountered are terpenes functionalized by thiocyanato, dichloroimine or isocyanato functional groups. ${ }^{1,2}$ Examples of the isocyanate functionality in the marine terpene literature include the bisabolene (1) ${ }^{3}$ and aromadendrane (2) ${ }^{4}$ sesquiterpenes, the amphilectane diterpenes 3-5, ${ }^{5,6}$ and the kalihinol A derivative 6. ${ }^{7}$ Novel biological activites have been described for these metabolites; compounds 3-5 are cytotoxic with $\mathbf{5}$ also showing potent and selective antiplasmodial activity, ${ }^{8}$ while $\mathbf{6}$ inhibits the metamorphosis of barnacle larvae. ${ }^{7}$ In contrast, isocyanate $\mathbf{2}$ is non toxic to fish and has been proposed to play a role in the detoxification of isocyano metabolites in Acanthella cavernosa. ${ }^{4}$ The recent reports of symmetrical sesquiterpenes containing urea functionality in marine sponges ${ }^{9-11}$ hint at a possible role of isocyanates in their biosynthesis, and suggest that isocyanate metabolites might occur more widely in marine sponges than has been reported. 


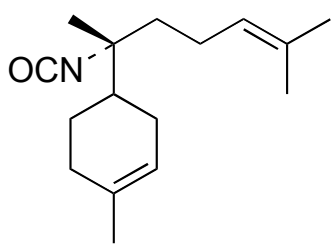

1

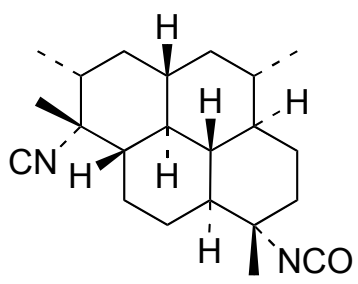

4

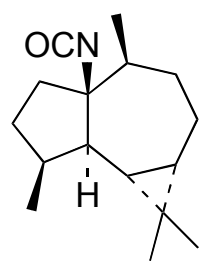

2

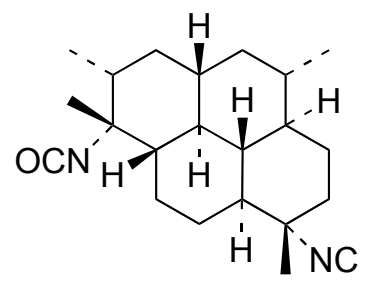

5

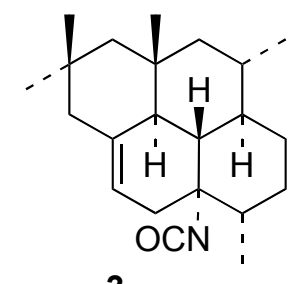

3

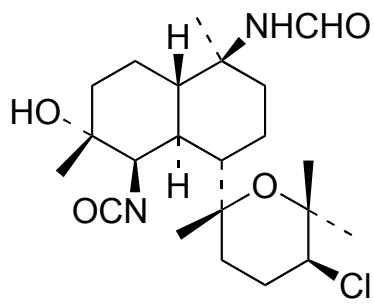

6

In this paper, we report the isolation of a new isocyanate with a spiroaxane skeleton from the well-known Indo-Pacific sponge Acanthella cavernosa, and describe a biomimetic reaction with menthyl isocyanate that may illustrate the role of terpene isocyanates in the formation of sponge natural products.

\section{Result and Discussion}

Four specimens of Acanthella cavernosa were collected at Tani's Reef, Mooloolaba, Australia in October 2004. Organic extracts from each sponge were examined by ${ }^{1} \mathrm{H}$ NMR, and by GC-MS which showed two clusters of peaks. A group of peaks with retention time between $10.0-12.0$ mins and $\mathrm{m} / \mathrm{z}$ of 231 were characteristic of sesquiterpen isocyanides, and the other cluster with a retention time of $13.5-15.0 \mathrm{mins}$ and $\mathrm{m} / \mathrm{z} 263$ were characteristic of sesquiterpene isothiocyanates. In each extract, a peak with a retention time of $12.3 \mathrm{mins}$ and an $\mathrm{m} / \mathrm{z}$ of 247 was of interest since this corresponded to a sesquiterpene isocyanate metabolite. The extracts were then combined on the basis of the similar chemistry and fractionated by silica flash column chromatography followed by normal phase HPLC using ethyl acetate-hexane mixtures.

A fraction eluting from HPLC ( $0.25 \%$ ethyl acetate/hexane) using two columns in series was a mixture of two compounds by GC-MS with molecular ions at $m / z 247$ and 263. Examination of ${ }^{1} \mathrm{H}$ spectra showed a major component containing three methyl doublets plus a methyl singlet on a double bond, while all fifteen carbons of the terpene skeleton could be identified from 2D spectra, as was an isothiocyanate signal at $\delta_{\mathrm{C}} 129.2$. This component was identified as the spiroaxane metabolite axisothiocyanate- 3 by comparison with literature data. $^{12,13}$ The minor component corresponded to the isocyanate metabolite with $\mathrm{m} / \mathrm{z} 247$. The upfield regions of both ${ }^{1} \mathrm{H}$ and ${ }^{13} \mathrm{C}$ NMR spectra did not reveal the complexity expected for a mixture of terpenes, suggesting that the new metabolite had the same carbon skeleton as 7 . Thus 
the component was likely to be the isocyanate analogue 8 named as axisocyanate- 3 . The ${ }^{1} \mathrm{H}-{ }^{13} \mathrm{C}$ connectivities for the minor component were then assigned using gHSQC data. Proton signals at $\delta_{\mathrm{H}} 3.51$ and 5.14 correlated to signals at $\delta_{\mathrm{C}} 64.6$ and 124.7 that could be assigned as C- 6 and C-4 respectively. Table 1 compares the NMR data for 7 and $\mathbf{8}$. Generally the ${ }^{13} \mathrm{C}$ signal for an $-\mathrm{NCO}$ group occurs between $\delta_{\mathrm{C}} 120-135$, but no signal corresponding to this functionality could be identified in the ${ }^{13} \mathrm{C}$ spectrum of the mixture because of the small sample size. Fast relaxation of the ${ }^{14} \mathrm{~N}$ nucleus also limits the detection of the linear - NCO carbon signal.

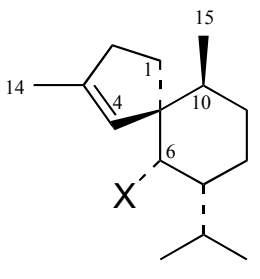

$7 \quad X=N C S$

$8 X=\mathrm{NCO}$

$9 \mathrm{X}=\mathrm{NHCSNEt}_{2}$

$10 \mathrm{X}=\mathrm{NHCONEt}_{2}$

$11 \mathrm{X}=\mathrm{NC}$

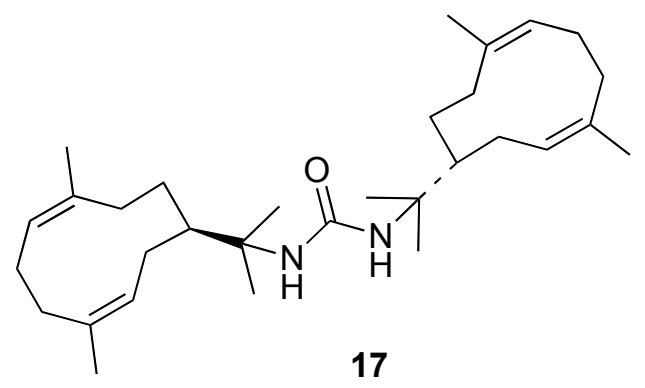

17<smiles>C=C1CCC[C@]2(C)CC[C@H](C(C)C)[C@H](NC(=O)NC3[C@H](C(C)C)CC[C@]4(C)CCCC(=C)[C@]34C)C12</smiles><smiles>CC(C)=CCC[C@](C)(NC(=O)N[C@](C)(CCC=C(C)C)C1CC=C(C)CC1)C1CC=C(C)CC1</smiles>

19

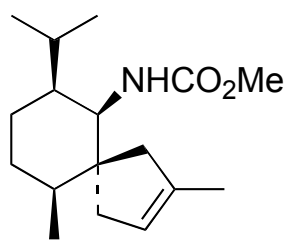

20

In order to confirm the presence of the isocyanate compound, the mixture of $\mathbf{7}$ and $\mathbf{8}$ was treated with diethylamine in DCM overnight at RT to give the thiourea 9 and urea $\mathbf{1 0}$. The ${ }^{13} \mathrm{C}$ NMR of the product mixture showed signals at $\delta_{\mathrm{C}} 180.6$ (thiourea) and $\delta_{\mathrm{C}} 156.9$ (urea) that had the anticipated correlations from the respective H-6 protons and from the diethylamine methylene protons in an HMBC spectrum. The two products were separated by NP HPLC (20\% ethyl acetate/hexane) and their individual ${ }^{1} \mathrm{H}$ spectra recorded. The data for compound $\mathbf{1 0}$ were fully in accordance with the proposed spiroaxane skeleton. The $[\alpha]_{\mathrm{D}}$ values for $\mathbf{9}$ and $\mathbf{1 0}$ were both positive, as are the values recorded for the parent axisonitrile-3 $\mathbf{1 1}^{12,14}$ and axisothiocyanate$37,{ }^{12}$ hence the series of compounds are likely to share the same absolute stereochemistry shown. ${ }^{14}$ 
Table 1. NMR data $\left(\mathrm{CDCl}_{3}, 500 \mathrm{MHz}\right)$ for axisothiocyanate-3 (7) and axisocyanate-3 (8) and their diethyl(thio)urea derivatives (9) and (10)

\begin{tabular}{|c|c|c|c|c|c|c|}
\hline No. & $\delta{ }^{1} \mathrm{H} 7$ & $\delta^{1} \mathrm{H} 8$ & $\delta^{13} \mathrm{C} 7$ & $\delta^{13} \mathrm{C} 8$ & $\delta^{13} \mathrm{C} 9$ & $\delta{ }^{13} \mathrm{C} \mathbf{1 0}$ \\
\hline $1 \mathrm{a}$ & 1.92 & 1.92 & 35.0 & 35.2 & 32.4 & 32.4 \\
\hline $1 b$ & 1.89 & 1.89 & & & & \\
\hline $2 a$ & 2.24 & 2.24 & 35.9 & 36.0 & 36.1 & 36.0 \\
\hline $2 b$ & 2.24 & 2.24 & & & & \\
\hline 3 & - & - & 144.8 & 144.1 & 143.5 & 142.9 \\
\hline 4 & 5.12 & 5.14 & 123.9 & 124.7 & 125.3 & 125.6 \\
\hline 5 & - & - & 58.9 & 58.8 & 60.6 & 60.6 \\
\hline 6 & 3.67 & 3.51 & 67.4 & 64.6 & 59.2 & 58.7 \\
\hline 7 & 1.24 & 1.24 & 45.4 & 45.2 & 45.0 & 45.0 \\
\hline $8 a x$ & 1.22 & 1.22 & 25.4 & 25.1 & 25.8 & 25.7 \\
\hline 8 eq & 1.78 & 1.78 & & & & \\
\hline $9 \mathrm{ax}$ & 1.08 & 1.08 & 31.3 & 31.3 & 31.9 & 31.1 \\
\hline $9 \mathrm{eq}$ & 1.50 & 1.50 & & & & \\
\hline 10 & 1.68 & 1.68 & 35.0 & 34.7 & 36.4 & 34.9 \\
\hline 11 & 1.50 & 1.50 & 30.1 & 30.0 & 29.5 & 29.5 \\
\hline 12 & 0.91 & 0.90 & 20.8 & 20.9 & 22.8 & 21.3 \\
\hline 13 & 0.89 & 0.87 & 20.4 & 20.3 & 20.6 & 20.6 \\
\hline 14 & 1.74 & 1.72 & 17.0 & 17.0 & 17.1 & 17.0 \\
\hline 15 & 0.75 & 0.73 & 16.5 & 16.1 & 16.5 & 16.4 \\
\hline NCS & - & - & 129.2 & - & & \\
\hline $\mathrm{NCO}$ & - & - & - & $\#$ & & \\
\hline $\mathrm{C}=\mathrm{S}$ & & & & & 180.6 & \\
\hline $\mathrm{C}=\mathrm{O}$ & & & & & & 156.9 \\
\hline
\end{tabular}

\# Signal not detected in 1D or HMBC spectra

Previous synthetic conversions of $(+)$-axisonitrile-3 11 to (+)-axisothiocyanate-3 7 using elemental sulphur had given rise to traces of a component with $\mathrm{m} / z 247$ in the crude reaction product which could now be identified as axisocyanate-3, but attempts to isolate this product were unsuccesful. We conducted biomimetic model studies on a menthyl-based skeleton in order to probe the chemistry of terpene isocyanates further. The menthyl-derived mesylate 12 was converted to axial azide 13 using $\mathrm{NaN}_{3}$ in DMF. ${ }^{15}$ Reduction of the azide using $\mathrm{LiAlH}_{4}$ in $\mathrm{Et}_{2} \mathrm{O}$ afforded amine $\mathbf{1 4}$ as the sole product. Following the procedure of Isobe et al., ${ }^{16}$ amine $\mathbf{1 4}$ was subjected to a two-phase mixture of phosgene equivalent, triphosgene, and aqueous sodium carbonate. Isolation of menthyl isocyanate 15 was attempted, however the product solidified on standing into the stable dimeric urea 16 (Scheme 1). Use of triethylamine ${ }^{17}$ instead of aqueous base led to the isolation of isocyanate $\mathbf{1 5}$ in $98 \%$. Coupling of isocyanate 15 with amine 14 at RT 
for $3 \mathrm{~h}$ also led to the formation of dimer 16. The formation of the bis-menthyl urea is a model reaction for the formation of symmetrical terpene metabolites such as the bis-germacrane urea 17, ${ }^{9}$ halichonadin A 18, ${ }^{10}$ and bis-bisabolene urea 19. ${ }^{11}$ The ready formation of ureas in sponges may reflect facile hydration and decarboxylation of an isocyanate metabolite followed by attack of the amine product on unreacted isocyanate, rather than an enzymatic reaction. Sponge metabolites such as exicarbamate $\mathbf{2 0}$ may also be diagnostic of isocyanate functionality. ${ }^{18}$

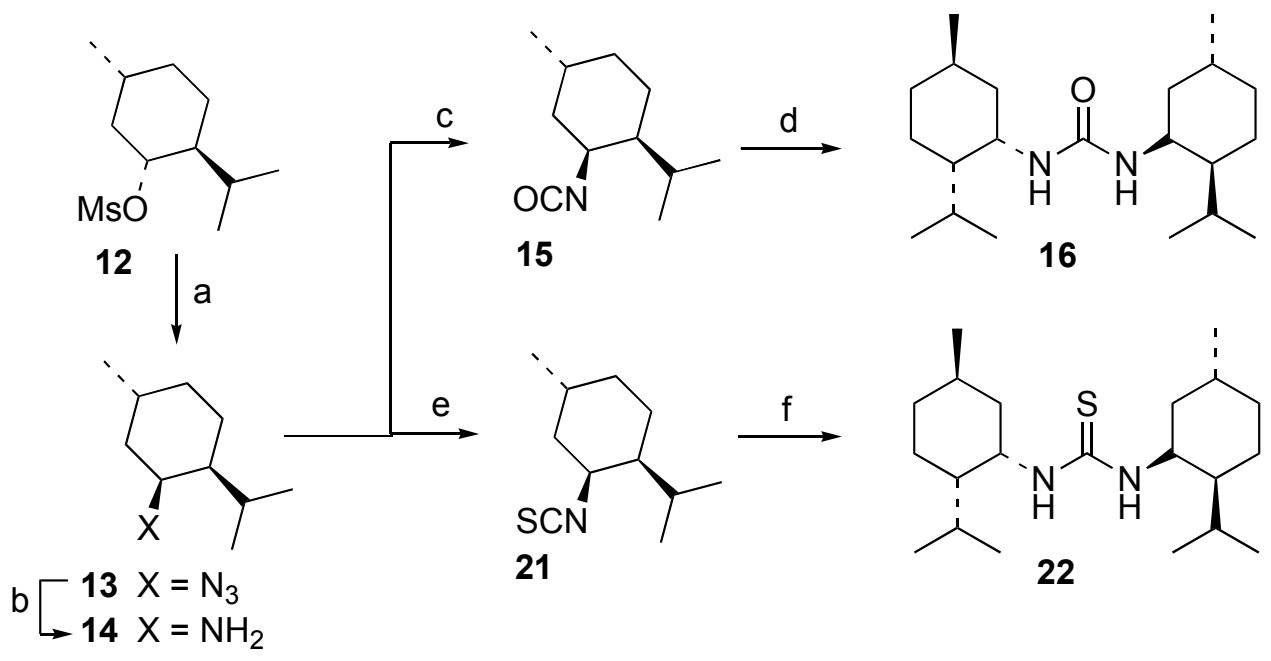

Scheme 1. a. $\mathrm{NaN}_{3}, \mathrm{DMF}, 80{ }^{\circ} \mathrm{C}, 42 \mathrm{~h}, 59 \%$; b. $\mathrm{LiAlH}_{4}, \mathrm{Et}_{2} \mathrm{O}, \mathrm{RT}, 21$ h, 51\%; c. Et 3 N, triphosgene, DCM, reflux, 2h, 98\%; d. cmpd 14, DCM, RT, 3h, 54\%; e. aq. $\mathrm{K}_{2} \mathrm{CO}_{3}$, thiophosgene, DCM, reflux, 30 mins, 68\%; f. cmpd 14, DCM, RT, 18h, 55\%.

Samples of synthetic compounds $14-\mathbf{1 6}$, and of a menthyl-based isothiocyanate 21 and dimeric thiourea 22 prepared according to Scheme 1, were subjected to antimicrobial and antiparasitic screens, but were without biological activity. The ${ }^{13} \mathrm{C}$ NMR spectrum of thiourea 22 contained two sets of signals consistent with the presence of rotamers.

\section{Conclusion}

Isocyanate metabolites are labile metabolites in marine sponges whose presence may frequently have gone undetected in isolation work owing to their sensitivity to hydrolytic conditions. By careful examination of a marine sponge extract, and by chemical derivatisation, evidence supporting the presence of axisocyanate-3 has been obtained. A model study using menthylbased intermediates reveals that terpene isocyanates readily convert into amine and urea analogues. 


\section{Experimental Section}

General experimental procedures. Optical rotations were obtained using a JASCO-P1010 polarimeter. One and two dimensional NMR spectra were acquired using Bruker DRX-500 or Bruker AMX-400 instruments. NMR spectra were obtained in deuterochloroform at room temperature. Samples were internally referenced to $\mathrm{CHCl}_{3}$ at either $\delta_{\mathrm{H}} 7.25$ and $\delta_{\mathrm{C}} 77.0$. High and low resolution mass measurements were obtained from a Finnigan MAT 900 XL-Trap electrospray (ESI) mass spectrometer with a Finnigan API III electrospray source. Gas chromatography/mass spectrometry (GC-MS) spectra were recorded on a Hewlett Packard 5890A gas chromatograph, carrying a DB5 capillary column in tandem with a Hewlett Packard 5970 mass selective detector or a Shimadzu GCMS-QP5050A gas chromatograph mass spectrometer, carrying a Zebron ZB-5 capillary column (30 mL x $0.32 \mathrm{~mm}$ ID x $0.25 \mu \mathrm{m}$ df, $5 \%$ phenyl polysiloxane) with a Shimadzu AOC-20i auto injector. Retention times were obtained using the following temperature ramping program: initial oven temperature $50{ }^{\circ} \mathrm{C}$ or $100{ }^{\circ} \mathrm{C}$; isothermal time 3.0 minutes, ramp $16^{\circ} \mathrm{C} \mathrm{min}^{-1}$; final oven temperature $270{ }^{\circ} \mathrm{C}$.

Biological material. Specimens of Acanthella cavernosa Dendy 1922 (Order Halichondrida family Dictyonellidae) were collected from Tani's Reef dive site at the Inner Gneerings, a group of shoals off Mooloolaba (Australia), using SCUBA at a depth of 10-15 m on 24 October 2004. Samples were taken back to the laboratory where they were stored at $-20^{\circ} \mathrm{C}$ until extraction. The sponge was dark orange in colour and globular in shape. A voucher specimen (QM G322184) is lodged at the Queensland Museum. Photographs of the sponge material are available from the authors.

Extraction and isolation of metabolites. Four frozen sponges ( $8.3 \mathrm{~g}$ each) were chopped finely and extracted with $\mathrm{CH}_{2} \mathrm{Cl}_{2} / \mathrm{MeOH}$ 1:1 (3 x $50 \mathrm{~mL}$ each). The extracts were filtered through a cotton wool plug, evaporated to aqueous suspension and partitioned between $\mathrm{H}_{2} \mathrm{O}(20 \mathrm{~mL})$ and ethyl acetate $(3 \times 70 \mathrm{~mL})$. The organic layers were combined, dried with anhydrous $\mathrm{MgSO}_{4}$ and evaporated to give dark orange crude extracts. Based on GC-MS analysis and comparison of ${ }^{1} \mathrm{H}$ NMR spectra, the crude extracts were combined into a single sample $(281 \mathrm{mg})$ and then flash chromatographed on silica gel using a solvent gradient $\left(100 \%\right.$ hexane - hexane $/ \mathrm{CH}_{2} \mathrm{Cl}_{2}$ 5:1, 1:1, 1:5 - 100\% DCM - EtOAc/ $\mathrm{CH}_{2} \mathrm{Cl}_{2}$ 5:1, 1:1, 1:5 - 100\% EtOAc - 100\% MeOH). The $100 \%$ hexane fraction contained sesquiterpene hydrocarbons including 9-aristolene ${ }^{7}(4.31 \mathrm{mg})$. The combined fractions eluting with $100 \%$ hexane and hexane $/ \mathrm{CH}_{2} \mathrm{Cl}_{2}(5: 1)(17.4 \mathrm{mg})$ were further purified by NP HPLC (two columns in series, $0.25 \%$ EtOAc/hexane, $2 \mathrm{~mL} / \mathrm{min}$ ) to give a mixture of axisothiocyanate-3 (7) ${ }^{12}$ and axisocyanate-3 (8) (1.84 $\left.\mathrm{mg}\right)$, an epimer of 10isothiocyanatoguai-6-ene ${ }^{19} \quad(1.10 \mathrm{mg}), \quad$ 10-isothiocyanato-4-cadinene, ${ }^{6}$ in addition to 1-isothiocyanatoaromadendrane $\mathrm{e}^{20}(6.58 \mathrm{mg})$ and $10 \alpha$-isothiocyanatoalloaromadendrane ${ }^{21}(0.44$ $\mathrm{mg}$ ). The next fraction eluting with hexane $/ \mathrm{CH}_{2} \mathrm{Cl}_{2}$ (5:1) contained acanthene $\mathrm{B}^{22}(1.08 \mathrm{mg})$. The fraction eluting with hexane/ $\mathrm{CH}_{2} \mathrm{Cl}_{2}$ (1:1) was further purified by NP HPLC (two columns in series, $0.5 \%$ EtOAc/hexane, $2 \mathrm{~mL} / \mathrm{min})$ to give axisonitrile-3 $(\mathbf{1 1})^{12,14}(4.18 \mathrm{mg})$ and 1 isocyanoaromadendrane ${ }^{20}(0.95 \mathrm{mg})$. 
Axisothiocyanate-3 $(7)^{12}$ colourless oil; $[\alpha]_{\mathrm{D}}{ }^{20}+152.3\left(c=0.3, \mathrm{CHCl}_{3}\right)$. GC-MS $m / z[\mathrm{M}]^{+} 263$ (65), 248 (15), 230 (15), 205 (2), 161 (6), 121 (100); ${ }^{1} \mathrm{H}$ and ${ }^{13} \mathrm{C}$ NMR see Table 1.

Axisocyanate-3 (8): colourless oil; GC-MS m/z [M] 247 (39), 232 (8), 205 (2), 161 (4), 121 (100); ${ }^{1} \mathrm{H}$ and ${ }^{13} \mathrm{C}$ NMR see Table 1.

Synthesis of thiourea (9) and urea (10) from a mixture of axisothiocyanate-3 (7) and axisocyanate-3 (8). A mixture of compounds 7 and $8(1.3 \mathrm{mg}, 4.94 \mu \mathrm{mol})$ was treated with diethylamine $(2.05 \mathrm{mg}, 0.028 \mathrm{mmol})$ in dry $\mathrm{CH}_{2} \mathrm{Cl}_{2}(9.4 \mu \mathrm{L})$ overnight at room temperature under $\mathrm{N}_{2}$. The $\mathrm{CH}_{2} \mathrm{Cl}_{2}$ was removed by a steady stream of $\mathrm{N}_{2}(\mathrm{~g})$ to give a mixture of thiourea (9) and urea (10) (0.95 mg, 57 \%). Separation by NP HPLC using 20\% EtOAc/hexanes (1 $\mathrm{mL} / \mathrm{min})$ gave thiourea $9(0.17 \mathrm{mg})$ followed by urea $10(0.10 \mathrm{mg})$.

Thiourea (9): white solid: $[\alpha]_{\mathrm{D}}{ }^{20}+26.2\left(c=0.013, \mathrm{CHCl}_{3}\right) ;{ }^{1} \mathrm{H}$ NMR $\left(\mathrm{CDCl}_{3}, 500 \mathrm{MHz}\right) \delta 5.24$ (1H, br s, H-4), 4.75 (1H, d, $J=10.0, \mathrm{H}-6), 3.66$ (4H, q, $J=7.0,14.5, \mathrm{H}-17$ and H-18), 2.38 (1H, m, H-2), 2.16 (1H, m, H-1), 2.08 (1H, m, H-2), 1.84 (1H, m, H-7), 1.72 (3H, s, Me-14), 1.57 (1H, m, H-8), 1.50 (1H, m, H-1), 1.35 (1H, m, H-11), 1.30 (1H, m, H-10), 1.22 (6H, s, Me-19 and Me-20), 1.18 (1H, m, H-9), $1.03(3 \mathrm{H}, \mathrm{d}, J=6.5, \mathrm{Me}-12), 0.90(1 \mathrm{H}, \mathrm{m}, \mathrm{H}-8), 0.83(3 \mathrm{H}, \mathrm{d}, J=$ 6.5, Me-13) and $0.77(3 \mathrm{H}, \mathrm{d}, J=6.5, \mathrm{Me}-15) ;{ }^{13} \mathrm{C} \mathrm{NMR}\left(\mathrm{CDCl}_{3}\right)$ see Table 1; HREIMS $\mathrm{m} / z$ $336.2596[\mathrm{M}]^{+}$(calcd. for $\mathrm{C}_{20} \mathrm{H}_{36} \mathrm{~N}_{2} \mathrm{~S} 336.2599(-1.0 \mathrm{ppm})$ ).

Urea (10): white solid; $[\alpha]_{\mathrm{D}}{ }^{20}+14.3\left(c=0.03, \mathrm{CHCl}_{3}\right) ;{ }^{1} \mathrm{H}$ NMR $\left(\mathrm{CDCl}_{3}, 500 \mathrm{MHz}\right) \delta 5.24(1 \mathrm{H}$, br s, H-4), 4.00 (1H, d, $J=10.0, \mathrm{H}-6), 3.25(4 \mathrm{H}, \mathrm{q}, J=7.5,14.5, \mathrm{H}-17$ and $\mathrm{H}-18), 2.38(1 \mathrm{H}, \mathrm{m}$, H-2), 2.16 (1H, m, H-1), 2.08 (1H, m, H-2), $1.78(1 \mathrm{H}, \mathrm{m}, \mathrm{H}-7), 1.70(3 \mathrm{H}, \mathrm{s}, \mathrm{Me}-14), 1.57(1 \mathrm{H}$, $\mathrm{m}, \mathrm{H}-8), 1.50$ (1H, m, H-1), 1.35 (1H, m, H-11), 1.27 (1H, m, H-10), 1.13 (6H, t, Me-19 and Me20), 1.18 (1H, m, H-9), $0.92(3 \mathrm{H}, \mathrm{d}, J=6.0, \mathrm{Me}-12), 0.87$ (1H, m, H-8), 0.84 (3H, d, $J=6.5$, Me-13) and $0.75(3 \mathrm{H}, \mathrm{d}, J=6.5, \mathrm{Me}-15) ;{ }^{13} \mathrm{C} \mathrm{NMR}\left(\mathrm{CDCl}_{3}\right)$ see Table 1; HREIMS $\mathrm{m} / \mathrm{z}$ $320.2823[\mathrm{M}]^{+}$(calcd. for $\mathrm{C}_{20} \mathrm{H}_{36} \mathrm{~N}_{2} \mathrm{O} 320.2828$ (-1.5 ppm)).

\section{Synthesis of monoterpene analogues}

(-)-Menthyl mesylate 12. To a solution of (-)-menthol (3 g, $19.2 \mathrm{mmol})$ in dry $\mathrm{CH}_{2} \mathrm{Cl}_{2}(55 \mathrm{~mL})$ was added pyridine $(31.05 \mathrm{~mL}, 384 \mathrm{mmol})$, a catalytic amount of DMAP $(0.1 \mathrm{~mol} \%)$, and methanesulfonic anhydride $(8.69 \mathrm{~g}, 50 \mathrm{mmol})$. After stirring at room temperature for $19 \mathrm{~h}$ the mixture was concentrated under reduced pressure and the residue diluted with $\mathrm{Et}_{2} \mathrm{O}(100 \mathrm{~mL})$. The resulting solution was washed with $2 \mathrm{M} \mathrm{HCl}$ made up in sat. aq. $\mathrm{NaHCO}_{3}(250 \mathrm{~mL})$ and the aqueous washings extracted with $\mathrm{Et}_{2} \mathrm{O}(100 \mathrm{~mL} \times 3)$. The combined organic phases were washed sequentially with $\mathrm{H}_{2} \mathrm{O}$ and sat. aq. $\mathrm{NaCl}$ and dried $\left(\mathrm{Na}_{2} \mathrm{SO}_{4}\right)$. Removal of the solvent in vacuo afforded crude mesylate as a yellow oil. The crude oil was subjected to column chromatography $\left(80 \% \mathrm{CH}_{2} \mathrm{Cl}_{2} /\right.$ hexane) to give mesylate 12 (4.49 g, $\left.19.2 \mathrm{mmol}, 100 \%\right)$ as a clear oil; ${ }^{1} \mathrm{H} \mathrm{NMR}$ $\left(\mathrm{CDCl}_{3}, 400 \mathrm{MHz}\right): \delta 4.52(1 \mathrm{H}, \mathrm{td}, J=4,12 \mathrm{~Hz}), 2.97(3 \mathrm{H}, \mathrm{s}), 2.26-2.20\left(1 \mathrm{H}_{e q}, \mathrm{~m},\right), 2.08-$ $2.00(1 \mathrm{H}$, dqn, $J=4,8 \mathrm{~Hz}), 1.72-1.62(2 \mathrm{H}, \mathrm{m}),, 1.51-1.35(2 \mathrm{H}, \mathrm{m}), 1.24\left(1 \mathrm{H}_{a x}, \mathrm{q}, \mathrm{J}=12 \mathrm{~Hz}\right)$, $1.03(1 \mathrm{H}, \mathrm{qd}, J=4,12 \mathrm{~Hz}),, 0.92(3 \mathrm{H}, \mathrm{d}, \mathrm{J}=4 \mathrm{~Hz}), 0.90(3 \mathrm{H}, \mathrm{d}, J=4 \mathrm{~Hz}), 0.87-0.83(1 \mathrm{H}, \mathrm{m})$, $0.80(3 \mathrm{H}, \mathrm{d}, J=8 \mathrm{~Hz}) ;{ }^{13} \mathrm{C} \mathrm{NMR}\left(\mathrm{CDCl}_{3}, 100 \mathrm{MHz}\right): \delta 83.3(\mathrm{CH}), 47.4(\mathrm{CH}), 42.2\left(\mathrm{CH}_{2}\right), 39.0$ $\left(\mathrm{CH}_{3}\right), 33.7\left(\mathrm{CH}_{2}\right), 31.6(\mathrm{CH}), 25.7(\mathrm{CH}), 23.0\left(\mathrm{CH}_{2}\right), 21.8\left(\mathrm{CH}_{3}\right), 20.7\left(\mathrm{CH}_{3}\right), 15.6\left(\mathrm{CH}_{3}\right)$; ESIMS m/z $257[\mathrm{M}+\mathrm{Na}]^{+}$. HRESI-MS $m / z 257.1179[\mathrm{M}+\mathrm{Na}]^{+}$(calcd. for $\mathrm{C}_{11} \mathrm{H}_{22} \mathrm{NaSO}_{3} 257.1187$ ). 
Azide 13. To a solution of (-)-menthyl mesylate 12 (2 g, $8.5 \mathrm{mmol})$ in anhydrous DMF (53 mL) was added sodium azide $(1.66 \mathrm{~g}, 25.6 \mathrm{mmol})$ and the mixture was stirred for $42 \mathrm{~h}$ at $80{ }^{\circ} \mathrm{C}$. The solution was cooled to room temperature, followed by addition of $\mathrm{Et}_{2} \mathrm{O}(50 \mathrm{~mL})$ and washed with $\mathrm{H}_{2} \mathrm{O}(3 \times 100 \mathrm{~mL})$, brine $(100 \mathrm{~mL})$, dried $\left(\mathrm{Na}_{2} \mathrm{SO}_{4}\right)$ and concentrated under reduced pressure to afford crude azide as a clear oil. The crude oil was subjected to column chromatography $(10 \%$ EtOAc/hexane) to give $13(0.907 \mathrm{~g}, 5.0 \mathrm{mmol}, 59 \%)$ as a clear oil; IR (thin film) $2105 \mathrm{~cm}^{-1}(\mathrm{~s})$; ${ }^{1} \mathrm{H} \mathrm{NMR}\left(\mathrm{CDCl}_{3}, 400 \mathrm{MHz}\right): \delta 3.96(1 \mathrm{H}, \mathrm{q}, J=4 \mathrm{~Hz}), 2.00(1 \mathrm{H}, \mathrm{qd}, J=4,16 \mathrm{~Hz}), 1.74-1.62$ $(4 \mathrm{H}, \mathrm{m}), 1.24-1.10(3 \mathrm{H}, \mathrm{m}), 0.92(3 \mathrm{H}, \mathrm{d}, \mathrm{J}=8 \mathrm{~Hz}), 0.88(6 \mathrm{H}, \mathrm{d}, \mathrm{J}=4 \mathrm{~Hz}) .{ }^{13} \mathrm{C} \mathrm{NMR}\left(\mathrm{CDCl}_{3}\right.$, $100 \mathrm{MHz}): \delta 60.5,47.3,38.9,34.8,29.5,26.5,24.9,22.2,20.9,20.6$.

Amine 14. Lithium aluminium hydride $(251 \mathrm{mg}, 6.6 \mathrm{mmol})$ in dry $\mathrm{Et}_{2} \mathrm{O}(11.42 \mathrm{~mL})$ was stirred at room temperature. To the stirred suspension was added dropwise the azide 13 (600 $\mathrm{mg}, 3.3$ mmol) dissolved in dry $\mathrm{Et}_{2} \mathrm{O}(16.08 \mathrm{~mL})$ and the mixture was brought to reflux for $2 \mathrm{~h}$ and then stirred at room temperature for $21 \mathrm{~h}$. Ice-cold $\mathrm{H}_{2} \mathrm{O}(20 \mathrm{~mL})$ was added carefully followed by $10 \% \mathrm{NaOH}(1 \mathrm{~mL})$. The solid was removed by filtration and the ethereal layer dried $\left(\mathrm{Na}_{2} \mathrm{SO}_{4}\right)$. Slow and careful removal of solvent gave amine $14(263 \mathrm{mg}, 1.69 \mathrm{mmol}, 51 \%)$ as a white solid that was used without further purification; mp $91-92{ }^{\circ} \mathrm{C} ;[\alpha]_{\mathrm{D}}{ }^{20}+6.5\left(c=0.54, \mathrm{CHCl}_{3}\right) ;{ }^{1} \mathrm{H}$ NMR $\left(\mathrm{CDCl}_{3}, 500 \mathrm{MHz}\right): \delta 3.2(1 \mathrm{H}, \mathrm{q}, J=3 \mathrm{~Hz}), 1.69-1.56(3 \mathrm{H}, \mathrm{m}), 1.44(2 \mathrm{H}$, br s $N H), 1.42$ $-1.35(1 \mathrm{H}, \mathrm{m}), 1.22-1.06(2 \mathrm{H}, \mathrm{m}), 0.89(3 \mathrm{H}, \mathrm{d}, J=10 \mathrm{~Hz}), 0.88(3 \mathrm{H}, \mathrm{d}, J=5 \mathrm{~Hz}), 0.86-0.84$ $(3 \mathrm{H}, \mathrm{m}), 0.83(3 \mathrm{H}, \mathrm{d}, J=5 \mathrm{~Hz}) ;{ }^{13} \mathrm{C} \mathrm{NMR}\left(\mathrm{CDCl}_{3}, 125 \mathrm{MHz}\right): \delta 47.9(\mathrm{CH}), 47.3(\mathrm{CH}), 43.1$ $\left(\mathrm{CH}_{2}\right), 35.3\left(\mathrm{CH}_{2}\right), 29.2(\mathrm{CH}), 25.6(\mathrm{CH}), 23.8\left(\mathrm{CH}_{2}\right), 22.5\left(\mathrm{CH}_{3}\right), 21.3\left(\mathrm{CH}_{3}\right), 20.6\left(\mathrm{CH}_{3}\right)$; EI-

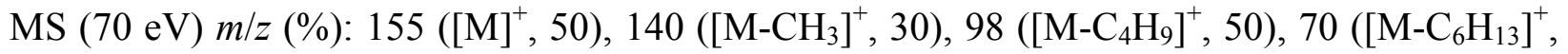
100). HRMS $m / z 155.1675[\mathrm{M}]^{+}$(calcd. for $\mathrm{C}_{10} \mathrm{H}_{21} \mathrm{~N} 155.1674$ ).

Isocyanate 15 . The amine $14(50 \mathrm{mg}, 0.32 \mathrm{mmol})$ and triethylamine $(65 \mathrm{mg}, 0.64 \mathrm{mmol})$ were dissolved in dry $\mathrm{CH}_{2} \mathrm{Cl}_{2}(4 \mathrm{~mL})$ and cooled to $0{ }^{\circ} \mathrm{C}$. Triphosgene (191 $\left.\mathrm{mg}, 0.64 \mathrm{mmol}\right)$ was added and the reaction was gradually brought to reflux for $2 \mathrm{~h}$. The reaction mixture was allowed to cool to room temperature and then filtered through a short pad of silica. The filtrate was concentrated in vacuo to afford isocyanate $15(57 \mathrm{mg}, 0.31 \mathrm{mmol}, 98 \%)$ as a clear oil that was used without further purification; $[\alpha]_{\mathrm{D}}^{20}+28.6\left(c=0.25, \mathrm{CHCl}_{3}\right)$; IR (thin film): $2271 \mathrm{~cm}^{-1}(\mathrm{~s})$; ${ }^{1} \mathrm{H}$ NMR (CDCl, $\left.400 \mathrm{MHz}\right): \delta 3.92(1 \mathrm{H}, \mathrm{q}, J=4 \mathrm{~Hz}), 1.88(1 \mathrm{H}, \mathrm{qd}, J=4,12 \mathrm{~Hz}), 1.77-1.61$ $(4 \mathrm{H}, \mathrm{m}), 1.45(1 \mathrm{H}, \mathrm{td}, \mathrm{J}=4,16), 1.25-1.08(3 \mathrm{H}, \mathrm{m}), 0.91(3 \mathrm{H}, \mathrm{d}, J=4 \mathrm{~Hz}), 0.89(3 \mathrm{H}, \mathrm{d}, J=8$ $\mathrm{Hz}), 0.87(3 \mathrm{H}, \mathrm{d}, J=4 \mathrm{~Hz}) .{ }^{13} \mathrm{C} \mathrm{NMR}\left(\mathrm{CDCl}_{3}, 100 \mathrm{MHz}\right): \delta 121.6(\mathrm{NCO}), 53.7(\mathrm{CH}), 47.8(\mathrm{CH})$, $41.7\left(\mathrm{CH}_{2}\right), 34.6\left(\mathrm{CH}_{2}\right), 29.9(\mathrm{CH}), 26.4(\mathrm{CH}), 2.8\left(\mathrm{CH}_{2}\right), 21.9\left(\mathrm{CH}_{3}\right), 20.8\left(\mathrm{CH}_{3}\right), 20.3\left(\mathrm{CH}_{3}\right)$; EI-MS (70 eV) m/z (\%): 181 ([M] $\left.]^{+}, 30\right), 124\left(\left[\mathrm{M}-\mathrm{C}_{4} \mathrm{H}_{9}\right]^{+}, 100\right), 95$ ([M- $\left.\left.\mathrm{C}_{5} \mathrm{H}_{10} \mathrm{O}\right]^{+}, 90\right)$. HRMS $m / z 181.1461[\mathrm{M}]^{+}$(calcd. for $\mathrm{C}_{11} \mathrm{H}_{19} \mathrm{NO} 181.1467$ ).

Urea 16. Isocyanate $15(10 \mathrm{mg}, 0.055 \mathrm{mmol})$ was treated with amine $14(17 \mathrm{mg}, 0.110 \mathrm{mmol})$ in dry $\mathrm{CH}_{2} \mathrm{Cl}_{2}(1 \mathrm{~mL})$ at room temperature for $3 \mathrm{~h}$. The precipitated product was collected by filtration, washed with $\mathrm{CH}_{2} \mathrm{Cl}_{2}$ and dried in vacuo to afford pure 16 (10 $\left.\mathrm{mg}, 0.030 \mathrm{mmol}, 54 \%\right)$ as a white solid; mp $282-285{ }^{\circ} \mathrm{C} ;[\alpha]_{\mathrm{D}}{ }^{20}+32.5\left(c=0.092, \mathrm{CHCl}_{3}\right) ;{ }^{1} \mathrm{H}$ NMR $\left(\mathrm{CD}_{3} \mathrm{OD}, 500\right.$ MHz): $\delta 4.07(2 \mathrm{H}, \mathrm{q}, J=5 \mathrm{~Hz}), 1.80-1.71(6 \mathrm{H}, \mathrm{m}), 1.53-1.45(2 \mathrm{H}, \mathrm{m}), 1.43-1.35(2 \mathrm{H}, \mathrm{m})$, $1.13(2 \mathrm{H}, \mathrm{dq}, J=5,15 \mathrm{~Hz}), 1.04-0.97(4 \mathrm{H}, \mathrm{m}), 0.94-0.91(2 \mathrm{H}, \mathrm{m}), 0.90(12 \mathrm{H}, \mathrm{d}, J=5 \mathrm{~Hz})$, 
$0.86(6 \mathrm{H}, \mathrm{d}, J=5 \mathrm{~Hz}) .{ }^{13} \mathrm{C} \mathrm{NMR}\left(\mathrm{CDCl}_{3}, 100 \mathrm{MHz}\right): \delta 157.5,47.7,46.5,40.3,34.7,29.5,26.7$, 25.3, 22.3, 21.0, 20.6; ESI-MS $m / z 359[\mathrm{M}+\mathrm{Na}]^{+}$; HRMS $m / z 336.3144[\mathrm{M}]^{+}$(calcd. for $\mathrm{C}_{21} \mathrm{H}_{40} \mathrm{~N}_{2} \mathrm{O} 336.3141$ ).

Isothiocyanate 21. A mixture of thiophosgene $(18 \mathrm{mg}, 0.156 \mathrm{mmol})$ and $\mathrm{CH}_{2} \mathrm{Cl}_{2}(0.104 \mathrm{~mL})$ was cooled to $-5{ }^{\circ} \mathrm{C}$ after which a solution of cooled $1 \mathrm{M}$ aq. $\mathrm{K}_{2} \mathrm{CO}_{3}(0.142 \mathrm{~mL})$ was added. A mixture of amine $14(22 \mathrm{mg}, 0.142 \mathrm{mmol})$ and $\mathrm{H}_{2} \mathrm{O}(0.03 \mathrm{~mL})$ was added dropwise over $15 \mathrm{~min}$ with vigorous stirring and maintaining of the temperature between $0-5{ }^{\circ} \mathrm{C}$. After stirring for an additional $10 \mathrm{~min}$ a cold $2 \mathrm{M}$ aq. $\mathrm{KOH}$ solution $(0.142 \mathrm{~mL})$ was added in one portion with cooling below $0{ }^{\circ} \mathrm{C}$. The organic layer and three extracts $\left(\mathrm{Et}_{2} \mathrm{O}\right)$ were dried over $\mathrm{MgSO}_{4}$ and subsequently concentrated under reduced pressure to afford crude isothiocyanate as a yellow oil. The crude was subjected immediately to column chromatography (100\% hexane) to give 21 (19 $\mathrm{mg}, 0.096 \mathrm{mmol}, 68 \%)$ as a clear oil; $[\alpha]_{\mathrm{D}}{ }^{20}+39.1\left(c=0.14, \mathrm{CHCl}_{3}\right)$; IR (thin film): $2120 \mathrm{~cm}^{-1}$ (s); ${ }^{1} \mathrm{H} \mathrm{NMR}\left(\mathrm{CDCl}_{3}, 500 \mathrm{MHz}\right): \delta 4.08(1 \mathrm{H}, \mathrm{q}, J=3 \mathrm{~Hz}), 1.88(1 \mathrm{H}, \mathrm{qd}, J=3,15 \mathrm{~Hz}), 1.81-$ $1.65(4 \mathrm{H}, \mathrm{m}), 1.55-1.48(1 \mathrm{H}, \mathrm{m}), 1.25(1 \mathrm{H}, \mathrm{dq} J=5,15 \mathrm{~Hz}), 1.13(1 \mathrm{H}, \mathrm{ddd}, J=5,15,15 \mathrm{~Hz})$, $1.00-0.94(1 \mathrm{H}, \mathrm{m}), 0.93(3 \mathrm{H}, \mathrm{d}, J=5 \mathrm{~Hz}), 0.91(3 \mathrm{H}, \mathrm{d}, J=5 \mathrm{~Hz}) 0.89(3 \mathrm{H}, \mathrm{d}, J=5 \mathrm{~Hz}) .{ }^{13} \mathrm{C}$ NMR $\left(\mathrm{CDCl}_{3}, 100 \mathrm{MHz}\right): \delta 129.7$ (NCS), 56.5, 47.9, 40.4, 34.3, 29.9, 26.6, 25.1, 21.7, 20.7, 20.9. EI-MS (70 eV) m/z (\%): 197 ([M] $\left.]^{+}, 70\right), 139$ ([M-NCS $\left.]^{+}, 60\right), 83\left(\left[\mathrm{M}-\mathrm{C}_{5} \mathrm{H}_{8} \mathrm{NS}\right]^{+}, 100\right)$; HRMS $m / z$ 197.1237 [M] $]^{+}$(calcd. for $\mathrm{C}_{11} \mathrm{H}_{19} \mathrm{NO} 197.1238$ ).

Thiourea 22. Isothiocyanate $21(5 \mathrm{mg}, 0.025 \mathrm{mmol})$ was treated with menthyl amine 14 (7.8 $\mathrm{mg}$, $0.051 \mathrm{mmol})$ in dry $\mathrm{CH}_{2} \mathrm{Cl}_{2}(0.5 \mathrm{~mL})$. The solution was stirred at room temperature for $18 \mathrm{~h}$. The thiourea was precipitated with the aid of pentane, filtered, washed with pentane and dried in vacuo to afford thiourea $21(5 \mathrm{mg}, 0.014 \mathrm{mmol}, 55 \%)$ as a white solid, mixture of rotational isomers 3:1 by ${ }^{1} \mathrm{H}$ NMR; $\operatorname{mp} 230-232{ }^{\circ} \mathrm{C} ;[\alpha]_{\mathrm{D}}{ }^{20}+61.1\left(c=0.018, \mathrm{CHCl}_{3}\right) ;{ }^{1} \mathrm{H} \mathrm{NMR}\left(\mathrm{CD}_{3} \mathrm{OD}\right.$, $500 \mathrm{MHz}): \delta 4.07(2 \mathrm{H}, \mathrm{q}, J=3 \mathrm{~Hz}), 1.99(2 \mathrm{H}, \mathrm{dd}, J=3,10 \mathrm{~Hz}), 1.84-1.71(4 \mathrm{H}, \mathrm{m}), 1.50-1.28$ $(2 \mathrm{H}, \mathrm{m}), 1.23-1.11(2 \mathrm{H}, \mathrm{m}), 1.09-0.94(8 \mathrm{H}, \mathrm{m}), 0.91-0.89(12 \mathrm{H}, \mathrm{m}), 0.86\left(3 \mathrm{H}_{\text {major }}, \mathrm{d}, J=10\right.$ $\mathrm{Hz},), 0.85\left(3 \mathrm{H}_{\text {minor }}, \mathrm{d}, \mathrm{J}=5 \mathrm{~Hz}\right) \mathrm{ppm} .{ }^{13} \mathrm{C} \mathrm{NMR}\left(\mathrm{CDCl}_{3}, 100 \mathrm{MHz}\right)$ major: $\delta$ 55.8, 46.4, 39.2, 34.4, 29.3, 26.3, 24.9, 22.2, 21.1, 20.6; minor: $\delta$ 55.8, 46.5, 40.8, 34.4, 29.7, 27.1, 24.9, 22.2, 20.9, 20.5; EI-MS (70 eV) m/z (\%): $352\left([\mathrm{M}]^{+}, 70\right), 215\left(\left[\mathrm{M}-\mathrm{C}_{10} \mathrm{H}_{17}\right]^{+}, 100\right) ; \mathrm{HRMS} \mathrm{m} / z$ $352.2921[\mathrm{M}]^{+}$(calcd. for $\mathrm{C}_{21} \mathrm{H}_{40} \mathrm{~N}_{2} \mathrm{~S} 352.2912$ ).

\section{Supplementary Information Available}

Figures S1-S16. ${ }^{1} \mathrm{H}$ and ${ }^{13} \mathrm{C}$ NMR data for compounds $7-\mathbf{1 0}, \mathbf{1 2}, \mathbf{1 4}-\mathbf{1 6}$, and $21-22$.

\section{Acknowledgements}

We thank the Islamic University of Indonesia for a scholarship (to P.J.), the Australia Research Council for funding, G. MacFarlane of the School of Molecular and Microbial Science, UQ, for mass spectrometric assistance, Prof. R. Capon, Institute for Molecular Bioscience, UQ, for 
assistance with the measurements of $[\alpha]_{D}$ values, and Dr J.N.A. Hooper, The Queensland Museum, for sponge taxonomy. Dr A. Kotze (CSIRO) and Ms Gill Barnes (University of Canterbury, New Zealand) conducted biological assays. ScubaWorld Mooloolaba assisted with access to dive sites for the sample collection (under permit from the Department of Primary Industries and Fisheries, Queensland).

\section{References}

1. Garson, M.J.; Simpson, J.S.; Flowers, A.E.; Dumdei, E.J. In Studies in Natural Products Chemistry, Atta-ur-Rahman Ed.; Amsterdam, 2001; vol 21, p. 329.

2. Garson, M.J.; Simpson, J.S. Nat. Prod. Rep. 2004, 21, 164.

3. Gulavita, N.K.; De Silva, E.D.; Hagadone, M.R.; Karuso, P.; Scheuer, P.J. J. Org. Chem. 1986, 51, 5136.

4. Braekman, J.C.; Daloze, D.; Moussiaux, C.; Stoller, D.; Denebourg, F. Pure Appl. Chem. 1989, 61, 509.

5. König, G.M.; Wright, A.D.; Angerhofer, C.K. J. Org. Chem. 1996, 61, 3259.

6. Mitome, H.; Shirato, N.; Miyaoka, H.; Yamada, Y.; van Soest, R.W.M. J. Nat. Prod. 2004, $67,833$.

7. Hirota, H.; Tomono, Y.; Fusetani, N. Tetrahedron 1996, 52, 2359.

8. Wright, A.D.; König, G.M.; Angerhofer, C.K.; Greenidge, P.; Linden, A.; DesqueyrouxFaúndez, R. J. Nat. Prod. 1996, 59, 710.

9. Satitpatipan, V.; Suwanborirux, K. J. Nat. Prod. 2004, 67, 503.

10. Ishiyama, H.; Hashimoto, A.; Fromont, J.; Hoshino, Y.; Mikami, Y.; Kobayashi, J. Tetrahedron 2005, 61, 1101.

11. Sullivan, B.W.; Faulkner, D.J.; Okamoto, K.T.; Chen, M.H.M.; Clardy, J. J. Org. Chem. 1986, 51, 5134.

12. Di Blasio, B.; Fattorusso, E.; Magno, S.; Mayol, L.; Pedone, C.; Santacroce, C.; Sica, D. Tetrahedron 1976, 32, 473.

13. Dumdei, E.J.; Flowers, A.E.; Garson, M.J.; Moore, C.J. Comp. Biochem. Physiol. 1997, 118A, 1385.

14. Caine, D.; Deutsch, H. J. Am. Chem. Soc. 1978, 100, 8030.

15. White, J. D.; Hansen, J. D. J. Am. Chem. Soc. 2002, 124, 4950.

16. Ichikawa, Y.; Nishiyama, T.; Isobe, M. J. Org. Chem. 2001, 66, 4200.

17. Osborn, H. M. I.; Williams, N. A. O. Org. Lett. 2004, 6, 3111.

18. Uy, M.M.; Ohta, S.; Yanai, M.; Ohta, E.; Hirata, T.; Ikegami, S. Tetrahedron 2003, 59, 731.

19. Jumaryatno, P.; Blanchfield, J.T.; Garson, M.J., unpublished data.

20. Mayol, L.; Piccialli, V.; Sica, D. Tetrahedron 1987, 43, 5381.

21. Ciminiello, P.; Fattorusso, E.; Magno, S.; Mayol, L. Can. J. Chem. 1987, 65, 518.

22. Burgoyne, D.L.; Dumdei, E.J.; Andersen, R.J. Tetrahedron 1993, 49, 4503. 